\title{
Climate justice: the urgent research agenda(s)
}

\section{Paul G. Harris}

Climate change has moved rapidly from the fringes of scientific research to become a topic that is central to debates among scholars from a wide variety of disciplines. It is now a front-burner issue for governments, businesses, civil-society organizations and publics. As the science of climate change has improved, and as its impacts have been increasingly felt around the world, it has become clearer that this issue is about much more than changes to the natural environment. It is also about politics and the distribution of scarce resources among and within national communities. It is about harsh impacts being felt by some more than others, not least by those individuals and communities least responsible for causing the problem. It is about the disproportionate responsibility of the world's affluent people and nations. In short, climate change is a matter of equity, fairness and social and distributive justice. Addressing climate change squarely requires research that enables a complete comprehension of the importance and implications of justice.

This book aims to advance a research agenda for climate justice that can help to illuminate new pathways forward for scholars (including advanced research students), policymakers, diplomats, practitioners and activists. A key objective of the book is to showcase and stimulate innovative, alternative perspectives on climate justice. Each chapter challenges assumptions and prevailing practices, thereby showcasing potential new directions for research and action on climate justice. In addition to furthering climate justice as a scholarly field, the book aims to have real-world impact by sharing new ideas that will inform and guide those doing the actual work of realizing it. As an introduction to subsequent chapters, in this one I very briefly introduce the problem of climate change and related policies, delineate the concept of climate justice, highlight some other books that have explored this topic recently, and summarize the contributors' individual agendas and arguments.

\section{Climate change and the weakness of climate policy}

Scientists first hypothesized in the nineteenth century that warming of the atmosphere would result from so-called greenhouse gases, but it was not until the 1980s that climate change started to receive widespread attention by both scientists and governments (cf. Harris 2019: 4-5). Since then, understanding of the issue has 
accelerated, with the latest research confirming many people's worst fears: massive anthropogenic emissions of greenhouse gases from human activities, especially global emissions of carbon dioxide from the combustion of fossil fuels, are changing Earth's climate system in profound ways (IPCC 2013). The atmosphere is growing warmer, as are its oceans, leading to myriad negative impacts, including more severe weather events, sea-level rise, spread of disease vectors, losses in agricultural productivity and accelerating extinctions. Without very robust action by governments and other actors to reduce greenhouse gas emissions drastically - more or less bringing net global carbon emissions to a halt within little more than a generation - the impacts will be dangerous and severe. Indeed, even with action it is possible that global warming and other manifestations of climate change will increase rapidly, in part due to 'natural' releases of carbon dioxide and other greenhouse gases from changing ecosystems (e.g. releases from melting permafrost and warming boreal forests).

The real dangers of climate change in the very near future, and the impacts predicted for coming decades and beyond, have started to stimulate action by governments and other actors to mitigate greenhouse gas pollution and grapple with the impacts that are being felt already and will be much more so in the future. At the international level, states (variously referred to in this book as countries, nations and states) came together in the late 1980 s and early 1990 s to negotiate the United Nations Framework Convention on Climate Change (UNFCCC), an overarching agreement for state-led action that has as its core objective the prevention of 'dangerous anthropogenic interference with the climate system' (UNFCCC 1992: 9). Subsequent agreements, such as the 1997 Kyoto Protocol to the UNFCCC and the 2015 Paris Agreement on climate change, have resulted from almost continuous international negotiations and more or less yearly 'conferences of the parties' to the convention and related agreements (for a summary, see Harris 2018: 129-36). Very early in the climate change negotiations, questions and concerns about equity and justice, particularly international justice among negotiating states, arose and took on prominence (Harris 2001: 44-88). States agreed that their responses to climate change ought to be equitable, fair and just - although agreement on what this means in practice has never been fully determined. The closest to a consensus on the way forward was the principle of 'common but differentiated responsibility', whereby developed states accepted greater responsibility for causing and dealing with climate change. However, while this principle has been an accepted part of international climate negotiations for decades, it is typically practised in the breach. Few disagree that the richest states have greater responsibility - some would say that this is so because they contributed the most to causing climate change, while others would add that they also have special responsibilities due to their affluence (much as affluent people in domestic societies have special responsibilities, such as to pay higher tax rates to fund social welfare programmes) - but precisely which states have precisely how much responsibility has never been agreed, partly because some of them look to newly developed states (China being the most obvious example) as being a bigger part of the problem and being more capable of taking on greater responsibility. 
Nationally, governments have started to take concerted action on climate change. Policies have been put in place in most developed states to reduce (or at least slow) greenhouse gas emissions. This has been done through a range of policies, such as regulation of energy-generation and transport industries, taxes, subsidies and education. Even in most developed states where there is scepticism among some politicians about taking action to reduce greenhouse gas emissions, most notably the United States (wherein, under President Donald Trump, the federal government has actively sought to undermine existing climate-related policies, prevent new ones and even promote the extraction, use and export of fossil fuels), greenhouse gas emissions have started to stabilize or decline. Partly this is due to the actions of sub-state actors, such as municipalities, as well as efforts by some industries either to become more energy efficient or to capitalize on alternative sources of energy. Many developed states have also provided funding - in keeping with their common but differentiated responsibilities - to developing states to help them prepare for climate change and develop in more environmentally sustainable ways, although the levels of funding for these purposes has been vastly less than what is needed (see Harris 2016b: 172-6).

Alas, despite these and countless other policies and actions to mitigate greenhouse gas pollution, global emissions are still growing (Pierre-Louis 2018). Indeed, even if all of the world's national governments were to fully implement their Paris Agreement pledges to limit those emissions, the objectives of that agreement to keep global warming to no more than $2^{\circ} \mathrm{C}$ above historical levels, and to try to limit warming to $1.5^{\circ} \mathrm{C}$ - would not be achieved; far from it (Climate Action Tracker 2018). Global warming has already exceeded $1^{\circ} \mathrm{C}$ (IPCC 2018: 51), and current policies will likely lead to global warming of well over $3^{\circ} \mathrm{C}$ (Climate Action Tracker 2018), to devastating effect. Even achieving the $1.5^{\circ} \mathrm{C}$ objective of the Paris Agreement would not prevent very major impacts and suffering around the world (IPCC 2018). In short, the problem is getting worse. Short of radical policy changes all around the world, the prospects are that the pollution causing climate change will continue for decades to come. Adding insult to injury, there is currently very little prospect of developed-state governments increasing financial and other assistance to developing states enough for the latter to cope adequately with the impacts of climate change. Without dramatic changes to the ways in which societies function, especially with respect to energy use, the injustices of climate change will be exacerbated as time passes.

\section{Climate justice}

Justice is about fairness, equity, impartiality and doing what is morally right. If something is unfair, inequitable, immoral or unreasonably partial (especially against those who are weak or toward those who are powerful or otherwise advantaged), it may be deemed to be unjust. With this in mind, in this book we conceive of climate justice broadly in terms of the fairness, equity and rightness of responses to climate change. (We do not focus on legal justice per se, although legal issues, 
both national and international, are clearly germane and thus do feature to varying degrees in many of the chapters.) We can perhaps understand the place of justice (and injustice) in the context of climate change most easily by thinking about relationships among actors, such as individuals, groups, organizations, corporations and government agencies, in local communities. If, within our communities, those with wealth and power are exploiting those with neither, we would normally describe that exploitation as unjust (despite the reality that it may occur as a matter of routine). More to the point, if a rich individual within a community were to pollute environmental resources relied upon by everyone in the community, for example by dumping pollution into a river that supplies drinking water to everyone downstream, most people would say that such activity is unjust (and many courts would agree because such activity would likely be unlawful). If a rich city were to dump its toxic rubbish onto a poor community, we might call that unjust, too. And if the hardship that arises from such activity were not compensated (and perhaps even if the perpetrators were not punished), most people would be inclined to say that justice has been denied.

All of these sorts of injustices, and many more, are occurring in the context of climate change, both within communities and globally. For example, climate change is a matter of justice because it involves the distribution of benefits and burdens globally and nationally. Some states and people are enjoying the benefits of polluting the global atmosphere while the burdens of doing so are being borne disproportionately by other states and peoples. Climate change is a matter of justice because its human causes will result in impacts that bring loss, hardship and suffering to many millions - and perhaps ultimately to billions - of people. Climate change is a matter of justice because the people who are least responsible for causing it, especially the world's poor, will suffer the most from it. Climate change is a matter of justice because the world's richest states and its most affluent people are disproportionately responsible for causing it. Climate change is a matter of justice because those who cause it often do so for non-essential, even frivolous reasons. Climate change is a matter of justice because those that do the most to cause it have the greatest capabilities to greatly reduce or stop their causative behaviours. Climate change is a matter of justice because those who are causing it are not doing nearly enough to aid those who do and will suffer from it. Climate change is a matter of justice because people in the present are voluntarily or unnecessarily harming people in the future. Climate change is a matter of justice because many people are behaving in ways that do, and increasingly will, undermine and destroy natural habitats and lead to the extinction of countless other species. Climate change is a matter of justice for countless other reasons.

\section{A blossoming literature on climate justice}

This book is intended to build upon existing literature on climate justice, particularly that which has appeared since the turn of the century. In recent years, the number of publications on climate justice has ballooned. This has been manifested 
in hundreds of scholarly journal articles on every aspect of climate justice (for a curated selection of several dozen articles within this genre, see Harris 2016a). From being a relatively rare topic in book-length literature on climate change in the 1990 , it is now commonplace for climate justice to be given at least some attention in most books about climate change. Quite a number of books published since the turn of the century are dedicated largely or wholly to climate justice. These include, for example, Page (2006), Vanderheiden (2008), Harris (2010), Humphreys (2010), Posner and Weisback (2010), McKinnon (2011), Shue (2014) and Tremmel and Robinson (2014).

Examples of books from just the last five years (2015-19) that focus much or all of their attention on climate justice include, among others, Aaron Maltais and Catriona McKinnon's (2015) edited book, which devotes several chapters to questions of climate equity and justice; Jeremy Moss's (2015) analysis, in collaboration with other scholars, of key problems associated with climate justice; Wen Stephenson's (2015) description of the lives of activists trying to achieve climate justice; Dominic Roser's (2016) introduction to climate justice and his co-edited volume with Clare Heyward (Heyward and Roser 2016) that considers the role of climate justice, and related questions of moral theory, in non-ideal circumstances; Randall S. Abate's (2016) collection of case studies on the regional and global implications of the disproportionate burdens of climate change that are felt by poor and marginalized people around the world; Christopher J. Preston's (2016) edited volume on the implications for climate justice of geoengineering (i.e., intentional large-scale efforts to 'engineer' Earth's climate system); Paul G. Harris's (2016b) survey and critical analysis of cosmopolitan 'global' justice and climate change (see his chapter with Alix Dietzel in this book); Luke Tomlinson's (2016) detailed study of procedural fairness in negotiations leading to the UNFCCC; Tracey Skillington's (2017) look at how denial of human rights has resulted in climate change and how strengthening human rights might promote climate justice; Olivier Godard's (2017) exploration of the 'diversified and conflicting intellectual landscape of the idea of global climate justice' (Godard 2017: 4); and Lukas H. Meyer and Pranay Sanklecha's (2017) edited volume in which scholars analyse the central debates regarding responsibility for historical emissions of greenhouse gases and what this means for the formulation of just climate policies.

The number of books on climate justice appearing in the last year or so (2018-19), not to mention those that are forthcoming, is remarkable. They include, for example, Mary Robinson's (2018) memoir, in which she argues that addressing climate change is essential to realizing global justice; Byron Williston's (2018) exploration of international and intergenerational justice as central themes in the ethics of climate change; Anna Roosvall and Matthew Tegelberg's (2018) investigation of the nexus of media and indigenous peoples in 'transnational' climate justice; Stefan Gaarsmand Jacobsen's (2018) collection in which a number of scholars look at the economic aspirations of the global movement for climate justice; R. Scott Frey, Paul K. Gellert and Harry F. Dahms's (2018) edited book in which several chapters look at some of the injustices of climate change, especially as they relate to historical global inequalities; Tahseen Jafry's (2018) comprehensive edited 'handbook' 
dedicated to climate justice, which surveys much of the landscape of this topic; Alix Dietzel's (2019) cosmopolitan-oriented look at the roles that non-state actors play in climate action and justice (see her chapter with Paul G. Harris later in this book); John S. Dryzek and Jonathan Pickering's (2019) book on the politics of the Anthropocene - the current period in Earth's history, during which humans have become the decisive force in shaping the Earth system, particularly its ecology - in which the authors focus substantial attention on what they call 'planetary justice'; Ravi Kanbur and Henry Shue's (2019) collection of chapters that brings together the perspectives of economists and philosophers on how to understand and implement climate justice (Shue is arguably the most prominent scholar of climate justice, with much of his working building on his argument for 'basic rights' from the 1980s (see Shue 1996, 2014)); and Megan Blomfield's (2019) development of a theory of global resource egalitarianism that, like Dietzel (2019) and Harris's (2016) books, challenges traditional conceptions of state sovereignty in the context of climate change.

The upshot is that climate justice research has joined mainstream scholarship on climate change. This is a positive development, but the knowledge and awareness that have been created in this area remain inadequate. Research and writing about climate justice are on the increase, but so, too, are the injustices of climate change. Much more research is needed, and soon, and vastly more effort is needed to translate resulting ideas into action. The chapters in this book signify steps in that direction.

\section{Agendas for climate justice}

In the chapters that follow, the contributors present innovative ways of conceptualizing and realizing climate justice. They critique mainstream ways of thinking about (and theorizing) climate justice. They attempt to push the boundaries of prevailing practice on climate justice. Many of their arguments are intentionally provocative because provocation may be what is needed to shake both scholars and practitioners out of established ways of thinking and customary ways of acting that have, for decades, failed to prevent most of the injustices of climate change from increasing.

\section{Vital needs of humans and non-humans}

We begin in Chapter 2 with an exploration of vital needs and climate justice by Robin Attfield. Attfield argues that we need to consider inter-human, intergenerational and inter-species perspectives when building the foundations for climate justice. Systematic studies of environmental (in)justice, beginning decades ago, have revealed that environmentally harmful activities are often located close to poor and dispossessed people. Such environmental injustices are now widespread, an obvious example being the placement of garbage dumps in the vicinity of (or even within) poor communities (and never within the richest ones). Such activities engender substantive, procedural and recognitional injustices. The growing environ- 
mental justice movement, in addition to emphasizing the impacts of environmental pollution on local communities, has also concerned itself with justice for future generations. According to Attfield, despite problems associated with explicating the rights of those living in the future, there might be circumstances in which they can justifiably be treated unfairly, as may occur when the interests - particularly vital ones - of those living in the present are prioritized while the interests of future generations are relatively discounted. From this perspective, preventing harm to future generations could amount to its own kind of injustice. Understanding why this could be the case, and getting a full picture of the scope of climate justice, requires us to consider the vital needs of other species alongside those of humans. To omit non-human creatures from the scope of justice could result in unjustly sacrificing the vital needs of non-human creatures to peripheral interests of humans. In evaluating this sort of perspective, Attfield maintains that environmental ethicists and policy-makers, if they are genuinely concerned about climate justice, ought to take all of these interests - human and non-human - fully into account.

\section{Identifying responsible agents}

In Chapter 3, Ivo Wallimann-Helmer critically examines agency for climate change in the context of common but differentiated responsibilities. He points out that ethical challenges presented by climate change routinely involve the just distribution of benefits (entitlements) and burdens, on one hand, and the fair differentiation of responsibilities, on another. The fairness of the latter will rely on principles of justice. The applicability of those principles, and the demands that they make, are dependent on several factors: the policy domains for mitigation, adaptation and 'loss and damage' associated with climate change; the agents (routinely identified as states) that bear the responsibilities; and the relevant policy levels - international, regional, national and local - of climate action. Wallimann-Helmer argues that the principle of common but differentiated responsibilities is more than a starting point for climate justice. It also shapes which demands for action on climate change are most appropriate for the different agents responsible for such action.

\section{Worldviews and climate justice}

From the perspective of David E. Storey, climate justice is and ought to be overwhelmingly cosmopolitan. (In Chapter 7, Alix Dietzel and Paul G. Harris advocate a cosmopolitan agenda for climate justice.) That said, in Chapter 4 Storey argues that the failure of ethics to penetrate sufficiently into climate policy, and indeed the inability of comprehensive and effective climate policy to gain political traction, requires something more. He argues that we ought to stop asking whether our accounts of climate justice are right or wrong and instead start asking why they have not been more effective. His chapter lays out a research agenda that consolidates moral philosophy and the social sciences to develop a potentially more effective approach to climate justice. He does this by first identifying three worldviews - traditional, modern and postmodern - that arguably have fuelled political and policy gridlock on climate change. He shows that debates about climate justice have 
often been framed as zero-sum conflicts between people who have 'modern' and 'postmodern' worldviews, on one side, and what he believes to be largely ignored people who have 'traditionalist' worldviews, on the other. To move beyond this conflict, and thereby to realize climate justice, Storey believes that it is necessary to find ways of framing justice and climate change, and also of communicating the benefits of climate policy, in ways that are likely to bring about a congruence of perspectives among the major worldviews.

\section{Spatial framing of injustices}

In Chapter 5, Ian Bailey also identifies different (and conflicting) ways of perceiving climate change as obstacles to realizing climate justice. He examines how notions of (in)justice are contested in national climate politics and looks at how competing conceptualizations of justice have shaped the development of policies intended to bring about decarbonization of national economies. He focuses on the role of 'spatial anchors' in the legitimization of justice arguments for (or against) new policy measures to address climate change. He does this by drawing upon evidence from actual experience in Australia, New Zealand, the United Kingdom and the United States. Analysis of that evidence reveals to Bailey that advocates of stronger mitigation policy frequently emphasize broader-scale concerns about the responsibility of wealthier states to take action. In contrast, those who want to obstruct or dilute climate policy initiatives often stress national welfare, inaction by other states or local justice concerns. The effectiveness of those who oppose robust climate policies in constructing spatially and socially recognizable discourses about the injustices of climate action has created major obstacles to climate-protecting policies. It has also undermined the influence of climate justice on political agendas. To increase the likelihood of realizing climate justice, Bailey argues that greater attention should be given to representing justice arguments in spatially imaginative ways.

\section{Capitalism, degrowth and climate justice}

In Chapter 6, Carlos Tornel also critiques prevailing ways of conceiving of climate justice and their failure to restrain the global forces, especially material economic growth, that are causing and exacerbating climate change. Indeed, Tornel argues that environmental non-governmental organizations, and the mainstream conceptions of climate justice that are advocated by an elite international managerial class, have relatively little beneficial significance. As he sees it, the dominant approaches to climate justice have systematically depoliticized, and thereby neutered, the demands of the climate justice movement. Climate change has been conceived of as a problem that requires technocratic and managerial solutions. This conceptualization has perpetuated a 'post-political' condition in which elite actors become involved but 'nothing really changes'. In response, in this century the objective of ending material economic growth - degrowth - has emerged as a social and academic movement. According to Tornel, a repoliticization of the climate justice movement is necessary to achieve climate justice, and degrowth offers a way to bring that about. The degrowth movement can do this by critiquing prevailing 
techno-managerial discourse, radically contesting calls for individual responsibility and collective action, and demanding revolutionary social transformation. For Tornel, solving the climate crisis and realizing climate justice requires moving beyond highbrow technological solutions, which most often arise from dominant discourses of ecological modernization and capitalism, toward genuine degrowth throughout the global economy.

\section{Cosmopolitan justice and non-state actors}

In Chapter 7, Alix Dietzel and Paul G. Harris explore the role of individuals and other non-state actors in doing the things that are necessary to realize climate justice. They argue that looking at climate change from a cosmopolitan perspective can help us to fully comprehend the practical and normative complexities of the problem. A cosmopolitan viewpoint discerns these actors' responsibilities in efforts to mitigate climate change, adapt to its impacts and aid those who do and will suffer from it. An agenda for cosmopolitan justice would help to move research and action beyond considering what states can and should do about climate change to focus much more attention on what non-state actors can and should do, and to some extent already are doing. As Dietzel and Harris note, there has been an explosion in the number of non-state actors involved with climate change. What is more, billions of individuals are capable of doing far more than they are at present. The climate regime, particularly following the 2015 Paris Agreement, has started to treat non-state actors as key agents of effective action. A cosmopolitan agenda for climate justice critiques states as exclusive holders of climate-related responsibility and vehicles for climate justice. Individuals and other non-state actors are also responsible and able to contribute to realizing climate justice. According to Dietzel and Harris, research for climate justice ought to take this fully into account.

\section{Social justice and ecological consciousness}

For individuals to take the action that is necessary to realize climate justice, it is necessary for them to be more ecologically conscious. As James S. Mastaler reminds us in Chapter 8 , there are many profound moral and social consequences arising from humanity's collective failure to reduce global greenhouse gas emissions. This failure has resulted in fundamental injustices against the world's poorest communities, which Mastaler argues necessitates new kinds of responses that are grounded on social equity and environmental responsibility. Together, these social and environmental attributes can form the foundation for the emergence of much greater ecological consciousness. Mastaler contemplates the development of ecological consciousness among individuals and across institutions, and he proposes a programme of essential tasks for realizing climate justice sooner rather than later. He introduces his own long-term vision for furthering climate justice. Social justice and ecological consciousness will be features of the structural changes that will have to be implemented if this is to happen. 


\section{Democratic institutions and environmental citizenship}

In Chapter 9, Giuseppe Pellegrini-Masini, Fausto Corvino and Alberto Pirni also explore institutional changes, focusing their arguments on the realization of climate justice through environmental citizenship. They believe that two key problems prevent individual and uncoordinated actions from addressing climate change effectively. The first problem is that epistemological and moral complexities often prevent individuals from fully comprehending their responsibilities toward present and future generations. The second problem is that even those individuals who overcome the first problem may fail to act - that is, change their behaviours to reduce their own greenhouse gas emissions - because they are caught up in habits of procrastination that are intended to avoid the relatively high short-term costs that they would face in doing so. Pellegrini-Masini, Corvino and Pirni introduce a number of institutional mechanisms and policies for fostering climate citizenship that could be implemented to help people overcome these problems. Climatecitizenship policies, such as personal carbon allowances, ombudspersons for future generations and parliamentary representational quotas for them, have the potential to influence citizens' climate-related behaviours, thereby assisting in the realization of climate justice.

\section{Justice for climate refugees}

In Chapter 10, Justin Donhauser examines one of the real-world manifestations of climate injustice: climate refugees. He asks whether it is necessary to develop new institutions and frameworks for recognizing the rights of climate refugees and the duties of those that ought to help them. He concludes that new mechanisms are not necessarily required. Avenues for realizing effective and just responses to increasing numbers of climate refugees can be found in existing United Nations refugee and climate-policy mechanisms, suggesting that action on this growing problem can and should occur soon. Donhauser looks at many of the relevant normative justice concerns that are unique to cases of climate refugees. He lays out typical legal explanations for not extending to climate refugees the rights to asylum, relief and non-refoulement (i.e., the right not to be sent back to a place from which one is fleeing persecution) that are currently available to other kinds of refugees. His chapter assesses five proposals for addressing climate refugees and proposes some ways by which those proposals might be put into practice to realize justice for them. Donhauser advocates addressing these issues using existing provisions of the UN Refugee Convention and the UNFCCC. He supports his argument by using new climate-event modelling methods that prioritize which matters of climate justice are the most urgent.

\section{Humanitarian crime and pre-emptive justice}

In Chapter 11, Selina Rose O'Doherty argues that climate change is a humanitarian crime. She highlights the correlation between climate justice in moral terms and climate justice in more strictly legal terms. As O'Doherty notes, international 
agreements to address climate change identify future targets for action rather than taking immediate steps to mitigate climate-changing pollution. This is apparently justified by some actions because the impacts of climate change being felt currently were caused by past pollution, and because the climatic impacts of behaviours occurring today will not be felt anytime soon. O'Doherty argues that this relatively slow and future-oriented approach to climate change is unjust. She asks us to imagine what the appropriate response would be if the consequences of climate change were caused deliberately and with contemporaneous effect. Her answer: those consequences would qualify as breaches of global justice. From this perspective - viewing the actions that cause climate change as intentionally violating the human rights of millions of people - would mean that they are crimes against humanity. Thus, they can be classified as humanitarian climate crimes. O'Doherty makes a case for pursuing climate justice on behalf of future victims through pre-emptive humanitarian intervention against actors that are responsible for causing climate change. International intervention against humanitarian climate crimes would be justified as both an ethical obligation and a sovereign responsibility under currently accepted international standards of humanitarian protection.

\section{Equity and justice in national pledges}

Most of the chapters in this book undertake broadly theoretical arguments and qualitative analyses to arrive at new ways of approaching climate justice. In contrast, in Chapter 12, Claire Swingle performs an empirical content analysis of Nationally Determined Contributions (NDCs) - that is, national action pledges - of the Paris Agreement on climate change to demonstrate nominal national attitudes toward questions of climate equity. To better understand how national governments conceptualize climate justice, Swingle analyses the 'Fairness and Ambition' sections of 163 NDCs. She compares each state's indicators of equity in its NDC against historical positions of its respective negotiating group in the international negotiations on climate change. She further compares the NDCs to each state's submission under the Talanoa Dialogue (the facilitative dialogues that were convened in 2018 to take stock of states' actions on climate change and inform the preparation of updated NDCs in 2020). Swingle's comparative analysis reveals some surprising findings. For example, historical responsibility, the mantra of developing countries for decades, is underemphasized in their NDCs and largely disconnected from common but differentiated responsibility. Instead, objectives to keep global temperatures below certain thresholds, and references to the importance of scientific reports, have been used in NDCs to build the case for enhanced ambition to reduce greenhouse gas pollution and to provide international support for developing countries. These findings are significant because the ways in which national governments perceive equity will affect how they assess the success (or lack of it) of global action on climate change, and subsequently how they shape their national climate policies. Those actions and policies will be crucial to realizing climate justice. 


\section{Responsibilities of the great powers}

In Chapter 13, Sanna Kopra argues that the great powers - China, the United States and other states recognized as having especially powerful status in international affairs - have greater responsibility for promoting climate justice than do most other states. He does this by drawing on the English School of International Relations theory, which posits that states form an international society and that great powers have special responsibilities in that society. By Kopra's reading, the English School has not paid very much attention to climate justice despite the fact that climate change is creating risks for international security and justice, and indeed will do so much more in the future. This is a gap in the literature that Kopra aims to fill in part with his chapter. He proposes that great powers can be expected to shoulder two types of special responsibility for climate change: managerial responsibility to prevent climaterelated conflicts from undermining international order, and leadership responsibility to promote human values through ambitious global climate policies. However, as Kopra points out, China, the United States and the UN Security Council (made up of great powers) have all failed to define their great-power responsibilities ambitiously enough to prevent dangerous climate change. Kopra advocates urgent research to develop the English School's normative viewpoints of great power responsibility and to use those to inform international negotiations on climate change and associated national policies. Realizing climate justice will require this.

\section{Conclusion}

The justice implications of climate change have been widely debated for decades. Calls for justice, particularly international justice, have been written into climate change agreements and conventions. Efforts to limit the injustices of climate change and to highlight them are also now part and parcel of the work of many non-governmental organizations, especially those concerned with environmental protection, economic development and poverty eradication. Increasingly, even some businesses have accepted that climate justice demands certain things of their behaviours. Appropriately, climate justice is now an established area of scholarship that crosses disciplinary boundaries, drawing the attention of natural and social scientists alike. Yet, despite the work of governments, scholars and activists to study and implement climate justice, the injustices of climate change - manifested in continued greenhouse gas pollution and, increasingly, the felt impacts of the changes they bring about - continue to worsen. Short of sweeping changes in individual and collective behaviours (which arguably would be worthwhile in any case because they can improve human well-being in numerous ways), there is little prospect of averting very serious climate change in the future.

Climate change is not only an environmental problem, nor is it primarily a problem of economics or politics. Climate change is fundamentally a problem of justice: injustice is at the root of its causes, at the heart of its impacts and vital to whether and how effective policies will be devised and implemented to mitigate 
the associated hardships. It would not be far-fetched to say that climate change is rapidly becoming the greatest injustice ever witnessed, experienced and indeed perpetrated across all of human history. Realizing climate justice under current circumstances will require doing far more in the very near future, and it will necessitate sustained action for many decades to come (at least). It will require new and innovative vision about the way forward. Without a new agenda - or new agendas - for researching, and therefore understanding, climate justice, not to mention accompanying new ways of acting to realize climate justice, the injustices of climate change will only multiply and intensify.

Each of the chapters that follow advocates its own potential research agenda for climate justice. Looked at collectively and holistically, they present a single research agenda for climate justice that is characterized by more attention (theoretically and practically) to justice in the context of climate change and, more specifically, greater effort to arrive at and implement alternative, even radical, conceptions of climate justice, sooner rather than later. Justice demands nothing less.

\section{References}

Abate, Randall S. (2016), Climate Justice: Case Studies in Global and Regional Governance Challenges, Washington, DC: Environmental Law Institute.

Blomfield, Megan (2019), Global Justice, Natural Resources and Climate Change, Oxford: Oxford University Press.

Climate Action Tracker (2018), 'Warming projections global update', accessed 29 May 2019 at https://climate actiontracker.org/documents/507/CAT_2018-12-11_Briefing_WarmingProjectionsGlobalUpdate_ Dec2018.pdf.

Dietzel, Alix (2019), Climate Justice and Climate Governance: Bridging Theory and Practice, Edinburgh: Edinburgh University Press.

Dryzek, John S. and Jonathan Pickering (2019), The Politics of the Anthropocene, Oxford: Oxford University Press.

Frey, R. Scott, Paul K. Gellert and Harry F. Dahms (eds) (2018), Ecologically Unequal Exchange: Environmental Injustice in Comparative and Historical Perspective, Cham: Palgrave Macmillan.

Godard, Olivier (2017), Global Climate Justice: Proposals, Arguments and Justification, Cheltenham, UK and Northampton, MA, USA: Edward Elgar Publishing.

Harris, Paul G. (2001), International Equity and Global Environmental Politics, London: Routledge.

Harris, Paul G. (2010), World Ethics and Climate Change, Edinburgh: Edinburgh University Press.

Harris, Paul G. (ed.) (2016a), Ethics, Environmental Justice and Climate Change, Cheltenham, UK and Northampton, MA, USA: Edward Elgar Publishing.

Harris, Paul G. (2016b), Global Ethics and Climate Change, 2nd edn, Edinburgh: Edinburgh University Press.

Harris, Paul G. (2018), 'Climate change: science, international cooperation and global environmental politics', in Gabriella Kutting and Kyle Herman (eds), Global Environmental Politics: Concepts, Theories and Case Studies, 2nd edn, London: Routledge, pp. 123-42.

Harris, Paul G. (ed.) (2019), Climate Change and Ocean Governance: Politics and Policy for Threatened Seas, Cambridge: Cambridge University Press.

Heyward, Clare and Dominic Roser (eds) (2016), Climate Justice in a Non-Ideal World, Oxford: Oxford University Press. 
Humphreys, Steven (ed.) (2010), Human Rights and Climate Change, Cambridge: Cambridge University Press.

Intergovernmental Panel on Climate Change (IPCC) (2013), Climate Change 2014: Synthesis Report, Cambridge: Cambridge University Press.

Intergovernmental Panel on Climate Change (IPCC) (2018), Global Warming of $1.5^{\circ} \mathrm{C}$, accessed 29 May 2019 at https://www.ipcc.ch/sr15/.

Jacobsen, Stefan Gaarsmand (2018), Climate Justice and the Economy: Social Mobilization, Knowledge and the Political, Abingdon: Routledge Earthscan.

Jafry, Tahseen (ed.) (2018), Routledge Handbook of Climate Justice, London: Routledge.

Kanbur, Ravi and Henry Shue (eds) (2019), Climate Justice: Integrating Economics and Philosophy, Oxford: Oxford University Press.

Maltais, Aaron and Catriona McKinnon (eds) (2015), The Ethics of Climate Change, London: Rowman and Littlefield.

McKinnon, Catriona (2011), Climate Change and Future Justice: Precaution, Compensation and Triage, London: Routledge.

Meyer, Lukas H. and Pranay Sanklecha (eds) (2017), Climate Justice and Historical Emissions, Cambridge: Cambridge University Press.

Moss, Jeremy (2015), Climate Change and Justice, Cambridge: Cambridge University Press.

Page, Edward A. (2006), Climate Change, Justice and Future Generations, Cheltenham, UK and Northampton, MA, USA: Edward Elgar Publishing.

Pierre-Louis, Kendra (2018), 'Greenhouse gas emissions accelerate like a "speeding freight train" in 2018', New York Times, accessed 24 May 2019 at https://www.nytimes.com/2018/12/05/climate/green house-gas-emissions-2018.html.

Posner, Eric A. and David Weisback (2010), Climate Change Justice, Princeton, NJ: Princeton University Press.

Preston, Christopher J. (ed.) (2016), Climate Justice and Geoengineering: Ethics and Policy in the Atmospheric Anthropocene, London: Rowman and Littlefield.

Robinson, Mary (2018), Climate Justice: Hope, Resilience and the Fight for a Sustainable Future, New York: Bloomsbury.

Roosvall, Anna and Matthew Tegelberg (2018), Media and Transnational Climate Justice: Indigenous Activism and Climate Politics, New York: Peter Lang.

Roser, Dominic (2016), Climate Justice: An Introduction, Abingdon: Routledge.

Shue, Henry (1996), Basic Rights, 2nd edn, Princeton, NJ: Princeton University Press.

Shue, Henry (2014), Climate Justice: Vulnerability and Protection, Oxford: Oxford University Press.

Skillington, Tracey (2017), Climate Justice and Human Rights, New York: Palgrave Macmillan.

Stephenson, Wen (2015), What We're Fighting for Now is Each Other: Dispatches from the Front Lines of Climate Justice, Boston, MA: Beacon Press.

Tomlinson, Luke (2016), Procedural Justice in the United Nations Framework Convention on Climate Change: Negotiating Fairness, New York: Springer.

Tremmel, Joerg Chet and Katherine Robinson (2014), Climate Ethics: Environmental Justice and Climate Change, New York: I.B. Tauris.

United Nations Framework Convention on Climate Change (UNFCCC) (1992), 'United Nations Framework Convention on Climate Change', New York: United Nations, accessed 31 May 2019 at http://unfccc.int/ files/essential_background/background_publications_htmlpdf/application/pdf/conveng.pdf.

Vanderheiden, Steve (2008), Atmospheric Justice: A Political Theory of Climate Change, Oxford: Oxford University Press.

Williston, Byron (2018), The Ethics of Climate Change: An Introduction, London: Routledge. 